\title{
Age, intellectual functions and activity contributions to elderly nutritional status
}

\author{
Isnani Nurhayati ${ }^{1}$, Anas Rahmad Hiadayat ${ }^{2}$ \\ ${ }^{1}$ Department of Nursing Academy, STIKES Mamba'ul 'Ulum, Indonesia \\ ${ }^{2}$ Department of Medical Records and Health Information, POLTEKKES Permata Indonesia, Indonesia
}

\begin{tabular}{|c|c|}
\hline Article Info & ABSTRACT \\
\hline Article history: & \multirow{11}{*}{$\begin{array}{l}\text { This research aimed to examine contribution of age, mental and activity } \\
\text { to the status of elderly nutrition. The research conducted in Boyolali, } \\
\text { Indonesia in December 2019-January 2020. This type of research } \\
\text { is quantitative with a cross sectional approach; determination of sampling } \\
\text { with purposive random sampling employed } 70 \text { respondents. Data analysis } \\
\text { was using Path Analysis with linear regression rate of significance } \\
\text { is } 0.05 . \text { The results showed that contributions of the age, intellectual functions } \\
\text { and simultaneous activities that directly affect the nutritional status } \\
\text { of } \mathrm{R}^{2} \text { square }=0.821=0.674 \text { or } 67 \% \text { while the remaining } 33 \% \text { are contributed } \\
\text { from other variables. The amount of simultaneous age and intellectual functions } \\
\text { contributions that directly affect elderly activities is } \mathrm{R}^{2} \text { square }=0.0327 \\
\text { or } 3.27 \% \text {, the remaining } 96.73 \% \text { is influenced by other factors. } \\
\text { Indirect contributions of age through activity to the status of elderly nutrition } \\
\text { and there is direct contribution of elderly intellectual functions condition } \\
\text { through activity to the status of elderly nutrition. }\end{array}$} \\
\hline Received Apr 19, 2020 & \\
\hline Revised May 22, 2020 & \\
\hline Accepted Jun 29, 2020 & \\
\hline & \\
\hline Keywords: & \\
\hline Activity & \\
\hline Age & \\
\hline Elderly & \\
\hline Intellectual & \\
\hline Nutritional status & \\
\hline
\end{tabular}

This is an open access article under the CC BY-SA license.

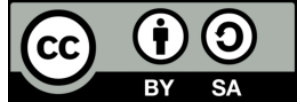

Corresponding Author:

Isnani Nurhayati,

Nursing Academy,

STIKES Mamba’ul 'Ulum Surakarta,

KM 03 Ring Road, Tawangsari, Mojosongi, Jebres, Surakarta, Jawa Tengah, Indonesia.

Email: 1sna@stikesmus.ac.id

\section{INTRODUCTION}

Fulfillment of nutritional needs for the elderly who are well-administered can help the process of adapting or adjusting to the changes they have, in addition it can maintain the continuity of changing the body cells so that it can extend the age. Elderly have the same necessities of life in order to live prosperous, the needs of the elderly include nutritious eating needs, health screening, decent housing, social welfare needs in a healthy mental condition. Similar conditions experienced by the elderly in Boyolali district, Central Java, Indonesia with some health conditions and activities that can affect the nutritional needs.

According to the Government regulation of the Republic of Indonesia number 43 year 2004, elderly is a person who has reached the age of 60 years and above. Based on the projected population of 2017, there are 23.66 million people of elderly people in Indonesia (9.03\%). Predicted number of elderly years 2020 (27, 08 million), year 2025 (33.69 million) year 2030 (40.95 million) and 2035 (48.19 million) [1]. The rate of population growth in Boyolali District is $0.59 \%$ starting in 2015-2017, this growth will increase with the quality of elderly life [2]. Life changes in the elderly pose various problems, including dependence on others, health disorders, and poverty. Decreasing the ability to respond to stress, repeated loss and physical change puts elderly at risk of disease and impaired bodily functions [3]. Increasing age, physiological function is decreased due to the aging process so that the disease is not contagious often occurs in the elderly one of them 
is hypertension, hypertension can be lowered by doing activities or movements through regular elderly gymnastics [4]. Health problems that often occur in the elderly are different from adults, called geriatric syndrome, which is a collection of symptoms that are about health and complained of by the elderly one of them is intellectual function. Dementia is a disorder of intellectual function and memory acquired caused by diseases of the brain, which is not related to impaired levels of consciousness, thereby affecting the work and social activities meaningfully. Dementia is not only a problem in memory. Dementia includes reduced ability to know, think, save or recall past experiences and also loss of touch patterns, patients become a taste, and disruption of activity [5]. Results of the research by Gela stated that dementia or Alzaimer often occurs in the elderly and efforts to relieve suffering, by routinely treating elderly conditions, to improve cognitive, neuropsychiatric, and motor symptoms and improve overall quality of life for patients and families [6].

Physical activity is the movement of body members that leads to the energy expenditure that is important for the maintenance of physical and mental health and maintains the quality of life to stay healthy and fit every day, but due to physical limitations possessed by age and changes in physiological function, eating elderly requires some adjustments in conducting daily physical activity. This physical activity affects elderly independence, one of which prepares their food needs. The level of elderly independence in fulfilling its daily needs is one of the factors that can affect the status of elderly nutrition. Increased reliability is caused by physical, psychological and social decline [7]. The decline experienced by the elderly resulted in disruptions in fulfilling the daily needs that could increase the help of others. For example, if eating, bathing, elimination and other activities must be assisted by the family, this condition if continuous will cause muscle weakness.

The results of the census to measure the elderly independence is obtained data that the ratio of elderly people to show that each year increased, year 2012 of 11.90 means that every 100 people productive should bear 12 olderly [8]. The assesment of independence in conducting daily activities is necessary to learn the level of further age to establish a life relief effort for the elderly and to conduct long-term care planning [9]. One of the risk factors of impaired nutritional needs in the elderly is dependence, whether it is family reliability, as well as care personnel, this condition is caused by decreased body function, muscle weakness and mobility ability that affects the status of elderly nutrients. The determination of elderly nutritional status can use the body mass index (BMI) through measuring body height, weight, abdominal circumference, upper middle arm circumference and waist circumference. Most of the elderly are overweight based on BMI and the risk of metabolic diseases based on waist circumference. According to mini nutritional assessment (MNA), 44.2\% have a normal nutritional status, $49.1 \%$ are at risk of malnutrition, $6.7 \%$ have malnourished [10].

The advantage of this study is to know the magnitude of contributions in determining the nutritional status of elderly views from their age, gender, mental status and activities that have not been studied by other authors. This study was conducted in Jelok village, Cepogo Boyolali. Jelok refers to one of the villages with the largest population in the district Cepogo, Boyolali with a population of about 4 million people, consisting of 4 RW (citizens association). Location of research in RW I, Sidosari with an elderly population of about 87 people. Location selection in RW I because it has the most number of elderly population compared with other RW, the elderly are more cooperative and various activism. The elderly lives in Jelok with various activities such as farmers, merchants and entrepreneurs. This research investigated the large and indirect contributions of causal relationships between age, gender, mental status of elderly activities and their impact on elderly nutritional status.

\section{RESEARCH METHOD}

This type of research was quantitative more with a cross sectional approach. Data collection using questionnaire that has been conducted validity test with Pearson Product Moment and reliability by using Cronbach Alpha formula. Popuasi is the whole elderly in Sidosari Hamlet Jelok Village. This village has the most number of elderly populations compared with other area; the elderly are more cooperative and various activisms with an elderly population of 87 . Sampling techniques using simple random sampling, i.e. sampling techniques usingthe formula Slovin obtained 70 respondents based on subjective and practical criteria or consideration, the elderly can provide information and cooperative in answering questions. Sample inclusion criteria are: an elderly age $>60$ years old, willing to be a respondent, can be a complement and cooperative. The independent variables of this study are age, intellectual function and day-to-night activities, while the dependencies variable is elderly nutritional status. The elderly self-reliance rate assessment is measured using the activity of daily living (ADL) index with independent categories, partial and dependent dependence [11]. Intellectual function uses short portable mental status quesioner (SPMSQ) with an intellectual function category, minor, moderate and severe damages and measurement of nutritional. Status assessed by the body mass index (BMI) with the category of good nutrition, insufficient 
and less [12]. Data analysis using the path analysis technique to test the amount of direct or indirect contributions manifested by the line coefficient on each diagrampath of the causal relationship between the X1 and $\mathrm{X} 2$ variables against the $\mathrm{Y}$ and its impact on $\mathrm{X}$, with linear regression on the significance rate of 5\%.

\section{RESULTS AND DISCUSSION}

\subsection{Characteristics of respondents}

Characteristics of respondents with a total of 70 elderly in Boyolali based on age groups, gender, level of self-reliance, mental status and nutritional status are presented in Table 1. The table shows that most of the elderly in Jelok village is 60-69 years old with a percentage of $62.86 \%$, male gender 36 people $51.43 \%$. The level of elderly self-reliance on average daily activities with independent categories amounted to 34 people $48.57 \%$. Average elderly intellectual function in the category of mild damage amounted to 34 people $48.57 \%$. The message of the elderly nutritional status amounted to 34 people $48.57 \%$ with good nutritional status.

\begin{tabular}{lcc} 
Table 1. Respondent's characteristic message \\
\cline { 2 - 3 } \multicolumn{1}{c}{ Age } & $\mathrm{F}$ & $\%$ \\
\hline $60-69$ & 44 & 62.86 \\
$70-79$ & 24 & 34.29 \\
$>80$ & 2 & 2.86 \\
Gender & 36 & 51.43 \\
Male & 34 & 48.57 \\
Female & & \\
Activity & 8 & 11.43 \\
Depending of total & 28 & 40.00 \\
Depends partly & 34 & 48.57 \\
Self & & \\
Intellectual functions & 0 & 0 \\
Severe damage & 22 & 31.43 \\
Moderate damages & 34 & 48.57 \\
Minor damages & 14 & 20 \\
Complete intellectual function & & \\
Nutritional status & 8 & 11.43 \\
Less & 28 & 40.00 \\
Enough & 34 & 48.57 \\
Good & $\mathbf{7 0}$ & $\mathbf{1 0 0}$ \\
Total & & \\
\hline
\end{tabular}

\subsection{Result of path analysis}

In order to test the amount of direct or indirect contributions manifested by the line coefficient on each track diagram of the causal relationship between the age variable, intellectual function to activity and its impact on elderly nutritional status using path analysis. Regression test Results Model 1 is the influence of age, mental and activities on the status of nutrition presented in Table 2. The regression results of Model I in the Table 2 age, intellectual functions and activity significant effect on nutritional status. The magnitude of the value of $\mathrm{R}$ square contained in Table 2 is 0.821 this indicates that the contribution or donation of the influence of age, intellectual functions and activity on the nutritional status of $82.1 \%$, while the remaining $17.9 \%$ is the contribution of other variables not included in this study.

Analysis results the path of age influence, mental status and the activity of elderly nutritional status in Table 3. Output regression model I on the Table 3 section. It can be known that the significance value in the age variable $=0.977$; the result is a winning that the age has no effect on the nutritional status. Significant value of intellectual function variable $=0.001$ and the activity of $<0.05$; these results indicate that intellectual functions and activity are influential on the nutritional status. Regression test Results Model II is the influence of mental status and age against the nutritional status presented in Table 4.

Model II regression results, namely age and mental status have significant effect on elderly activities. The size of the $\mathrm{R}$ square in Table 4 is 0,181 indicates that the contribution or donation of age and mental influence on the activity is $18.1 \%$, while the remaining $81.9 \%$ is the contribution of other variables not included in the study. Analysis results on the path of age influence, the status of Mental to elderly nutritional status is in Table 5 .

Output regression model II in the Table 5 section can be known that the significance value in the age variable $=0699>0.05$, the result is winning that the age has no effect on the activity, while the intellectual functions $=0.001<$ of 0.05 , this result indicates that intellectual functions affects the activity. The relationship 
of age, mental and activity against the status of elderly nutrition status are presented in Figure 1. In the figure seems that the age contribution through activity to nutritional status is 0.002 , the contribution of mental status through activity to nutrient status is 0.36 .

Table 2. Regression model 1age, intellectual function and activity affect nutritional status

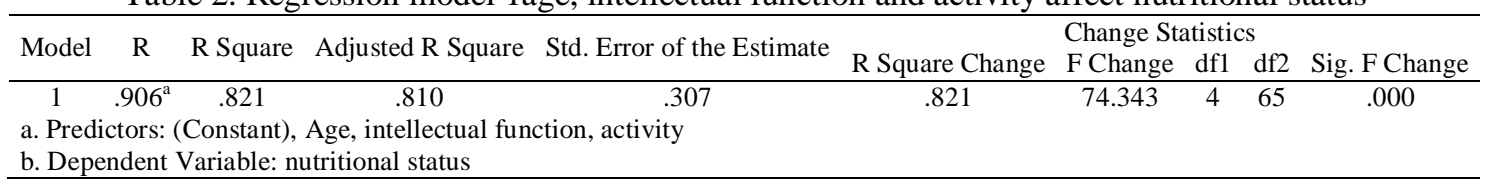

Table 3. Analysis path test result age, intellectual function and activity affect nutritional status

\begin{tabular}{|c|c|c|c|c|c|}
\hline \multirow{2}{*}{ Model } & \multicolumn{2}{|c|}{ Unstandardized Coefficients } & \multirow{2}{*}{$\begin{array}{c}\text { Standardized Coefficients } \\
\text { Beta }\end{array}$} & \multirow[b]{2}{*}{$t$} & \multirow{2}{*}{ Sig. } \\
\hline & B & Std. Error & & & \\
\hline 1 (Constant) & -.112 & .266 & & -.420 & .676 \\
\hline Age & .002 & .071 & .002 & .029 & .977 \\
\hline Intellectual function & .134 & .060 & .136 & 2.222 & .030 \\
\hline Activity & .858 & .059 & .841 & 14.494 & .000 \\
\hline a. Dependent Variable: & nutritional & & & & \\
\hline
\end{tabular}

Table 4. Regression model II age, intellectual function and activity

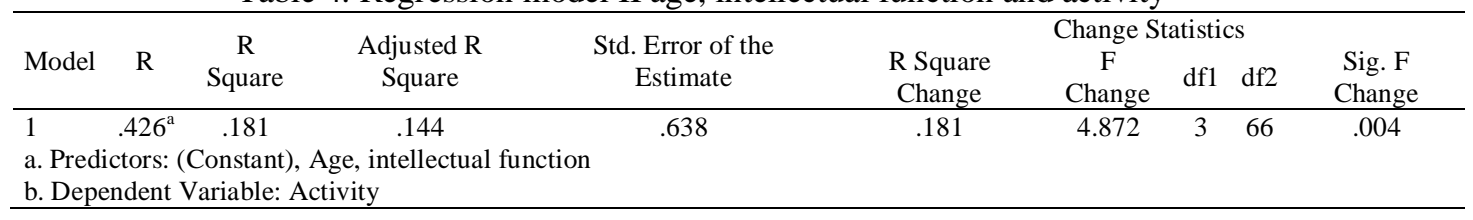

Table 5.Analysis path test result age and intellectual functionof elderly activities

\begin{tabular}{|c|c|c|c|c|c|c|}
\hline \multirow{2}{*}{\multicolumn{2}{|c|}{ Model }} & \multicolumn{2}{|c|}{ Unstandardized Coefficients } & \multirow{2}{*}{$\begin{array}{c}\text { Standardized Coefficients } \\
\text { Beta }\end{array}$} & \multirow{2}{*}{$\mathrm{t}$} & \multirow{2}{*}{ Sig. } \\
\hline & & B & Std. Error & & & \\
\hline 1 & (Constant) & 1.499 & .522 & & 2.869 & .006 \\
\hline & Age & -.058 & .148 & -.047 & -.389 & 699 \\
\hline & Intellectual function & .388 & .116 & .401 & 3.340 & .001 \\
\hline \multicolumn{7}{|c|}{ Dependent Variable: Aktivitas } \\
\hline
\end{tabular}

\subsection{Age contributions through activity to nutritional status}

Results of age impact analysis through activity to nutritional status in Tabel 3 and Figure 1. It is known that the effect of the age given to the nutritional status of 0.002 , while the indirect influence of the age through activity to the nutritional status is $-0.047 \mathrm{x} 0.841=-0.039$. Hence the total influence given age to nutritional status is $0.002+(-0039)=-0037$. Based on the results of the calculation above the direct influence of $0.002>-0.039$ indirect influence, this result indicates that indirectly the age through activity has nosignificant(negative) effect on nutritional status. The condition is likely due to the elderly that the majority of men aged 60-69 years $62.86 \%$ and have certain diseases, the elderly work of the majority of farming and gardening because Boyolali belongs to the mountainous area so that they do not pay attention to their nutritional intake as well as lack of nutritional knowledge.

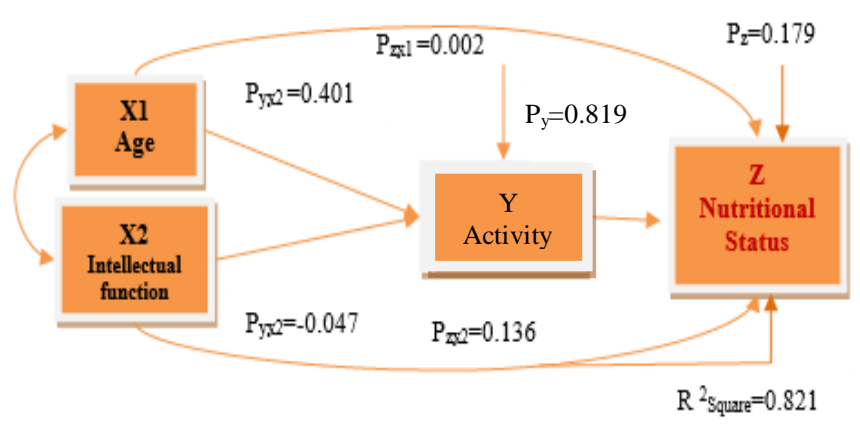

Figure 1. The pathway of causal relationship impairs age, intellectual function and activity to nutritional status 
Table 3 shows the contribution of age to the status of nutrition indirectly affects the nutritional status of $0.0022=0.00000=0.0004 \%$, very small of age affects the nutritional status of elderly. Table 5 shows that age contributions that do not directly affect activity amounting to- $0.0472=-0.0022=-0.220 \%$. In this opinion, Okala studies that the majority of parents are overweight based on BMI and the risk of metabolic diseases based on roasted circumference, not age based. According to MNA, 44.2\% have a normal nutritional status, $49.1 \%$ are at risk of malnutrition, $6.7 \%$ have malnourished. All beneficial nutritional intake is in accordance with the requirements of carbohydrates, proteins, terrorizing, except for calcium and magnesium [13], so that this age factor gives a contribution that is as valuable as the status of nutrition. The results were not in line with Ibrahim's research stating that age also has an effect on nutritional status [14]. It is theoretically mentioned that increasing age will cause the elderly to undergo changes in body organs that affect the disturbance of organ function and decrease in deficiency so that lean body mass decreases progressively.

In everyday life, human beings cannot be avoided from the aging process. In the elderly, there is a decline in brain function, resulting in decreased short-term recall, slowing down the ability to receive information, difficulty in knowing the objects, and doing daily activities called amnesia or senile. Age 45-78 years old has decreased and the difference between male and female, activity and muscle function. Muscle strength in the age of elderly will reduce the power of muscles because if excessive activity, it will be at risk of disability. With age Semakian increase, activities are also increasingly reduced. The high prevalence of falls in older people becomes a consequence of their diminished muscular strength [15]. The results of the study on Table 1 showed that the average elderly suffered mental damage by a total of 34 people $48.57 \%$, this condition suggests that elderly people can still use good thinking, controlling emotions are able to receive information from others well.

Increasing age, the elderly usually experience a decline in mental functioning. Starting from memory, mind acuity, until the ability to manage emotions can be interrupted. Especially if you've always worked all day before taking retirement. A brain that is not sharpened every day will rapidly decline its function. Physical activity is a way to train a healthy brain. When performing physical moves and activities, brain nerves will work and build healthy new cells to replace damaged or dead cells [16].

\subsection{Intellectual functions contributions through activity to elderly nutritional status}

Analysis of mental influence through activity on the nutritional status in Table 3 and Figure 1 show direct influence given mentally to the nutritional status of 0.136 , while indirect influence of gender through activity to nutritional status is $0.401 \times 0.841=0.337$ Hence the total influence given age to nutritional status is $0.136+0.337=0.473$. Based on the results of the above calculations that the direct influence value is 0.136 and the indirect effect of 0.473 which means that the value of indirect influence is greater than the value of direct influence, these results indicate that indirectly the gender through activity has a significant influence on nutritional status. Research conducted by Luis stated that the healthy nutritional Status of the study population is because they mostly habituate healthy eating, and especially for high levels of physical activity, if his physical activity is good then his statuas will also be well-researched with BMI [17].

Table 3 presents the contribution of intellectual function directly affects the nutritional status of $0.1362=0.018$ or $1.8 \%$. This indicates that the intellectual function has an effect on nutritional status, the better the intellectual function and the better the nutritional status. In Table 5 The contribution of intellectual function directly affects the activity of $0.4012=0.16$ or $16 \%$

Intellectual impairment is a collection of symptoms of the clinic consisting of impaired intellectual function and considerable memory that is adapted to cause disruption of daily life activities. This condition is rapidly increasing at the age of 60 to 85 years or older, which is less than 5\% of seniors aged 60-74 years experience dementia while the age after 85 of the incident was increased close to $50 \%$. The thing that can cause interlektual disorders is depression so it needs to be distinguished by other intellectual disorders [5] elderly mental conditions are often shown depressive symptoms. Symptoms of depression arising from the illness suffered by the elderly. Depression in the elderly is often not well diagnosed due to organic symptoms. Unhandled depression can reduce appetite, a passion for activity and can lower immunity of the body [18]. In line with Xiaolai's research stating that, the mental health of the older person significantly affects the nutritional needs, this is because in some aspects. First, when they have a high satisfaction status with life, social capital is correlated with better mental health. Secondly, consuming eating alone is associated with mental problems, such as depression, eating together which is beneficial for the mental health of older adults. Thirdly, as mentioned above, regular eating habits may reduce the incidence of mental illness, so that the feeding status is associated with a mental ststus [19].

The decline of intellectual function can be a forgetfulness of the most mild form of mental disorders, this disorder is estimated to be complained of 39\% elderly aged 50-59 years, increased to more than 85\% at the age of more than 80 years. Various psychological factors affecting the nutritional status of parents. The depression is increasingly known as a major health problem for elderly people, as a result of theirdepression, 
people may become incapable of conducting physical activity, including cooking and eating, and the appetite may change. Depression in the elderly is associated with chronic disease risk factors, including obesity [20]. This research is also reinforced by the opinion of Garibella which is said that patients with impaired muscle mass treated with 6 months of diving will experience a problem of intellectual function and effect on the nutritional status with $\mathrm{p}<0.05$ [21]. It is also with the research of Gracia stating that the nutritional strategies for cognitive enhancing by noting existing dietary components, because with adequate nutritional needs needed to optimize brain function and prevent cognitive decline [22].

Wang identified three trajectory of nutritional status: malnutrition (15.4\%), at risk for nutritional deficiencies $(38.9 \%)$, and nutrition $(45.7 \%)$. In contrast, mental changes followed four linear trajectories but differed: moderately disturbed $(12.2 \%)$, somewhat disturbed $(27.8 \%)$, impaired boundary $(21.8 \%)$, and mentally intact (38.2\%). Nutritional Status is significantly indifferent to mental functions, for example, relative to malnourished patients, patients who have nutrients well $95 \%$ less likely (or $=0.05, \mathrm{CI}=0.01-0.24$ ) to experience a fairly mental disorder [23].

In Table 1 the intellectual function showed most of the respondents suffered mild damage amounting to 34 people with a percentage of $48.57 \%$. Mild cognitive impairment into clinical diagnosis based on the results of neurological examinations, screening of mental status screening, and secondary testing. Causes of mild cognitive impairment include degenerative and vascular processes, psychology, and disease factors requiring long-term care [24].

Unlike the research conducted by Dema, this research indicates that there is no relationship between the BMI and mental function $(\mathrm{p}=0.217)$. It is can be happened due to in the BMI measurement there is a possibility of less yield accuracy, because one of the physiological that occurs in the elderly is the depreciation of the invertebralis discs that causes a high decrease in body [25].

\subsection{Contributions to elderly nutritional status}

In Table 3 the contribution of activity directly affects the nutritional status of $0.841=0.707$ or $70.7 \%$ of physical activity for the elderly should be adjusted to the conditions and physical abilities of each. WHO advocates that every elderly is expected to meet the physical needs of another 150 minutes of moderate-intensity physical activity or 75 minutes of heavy-intensity physical activity during the week. Every physical activity, make sure the duration lasts for at least 10 minutes if you are familiar with the minimum recommendation, get used to moderate physical activity for 300 minutes or heavy physical activity for 150 minutes a week. Elderly who have a problem of body coordination should do a balance exercise at least 3 times a week muscle exercises should be done at least 2 times a week. Physical exercise has been shown to improve functional status, help to prevent weakness and is an effective treatment for recovery. Poor nutritional status is associated with the occurrence of weakness. Early screening and diagnosis of poor nutrition and weakness in the elderly will help to prevent the occurrence of defects. Effective treatment is based on the correction of macro deficits and micronutrients and physical exercises [26].

\subsection{Age contributions, intellectual function and activity to elderly nutritional status}

The contribution of age, intellectual function and activity simultaneously directly affects the nutritional status of $\mathrm{R}_{\text {square }}^{2}=0.821=0.674$ or $67 \%$ while the remaining $33 \%$ are contributions from other variables not included in this study. The elderly who have a high level of self-reliance are the elderly who are physically well-primed, the high level of elderly self-reliance has been accustomed to completing the work in the household related to fulfillment. The results are in line with Alfianita's research that states the relationship of self-reliance and nutritional status, obtained the value of $P$ is $0.015(p<0.05)$ means there is a meaningful relationship between the level of independence in conducting daily life activities (ADL) with the status of elderly nutrition daily necessities [27]. The level of self-reliance in conducting daily life activities (ADL) is one of the factors affecting the status of advanced nutrition, both dependence on eating (bribing food and preparing food) and dependence in mobility. Dependence on the elderly both family and care officers is one of the risk factors of nutritional disorders in the elderly [28].

Sleep, eating, bathing and dressing, leisure activities, and light activities are the 5 most activities performed by the elderly. Next followed by walking, activities carried out by sitting, sweeping, washing clothes and plates without machines, and doing housework. This suggests that most habits of the elderly daily activities are less active. If the physical activity is seen, the distribution of samples with the most mild activity on the status of excess nutrients (92.7\%) [29].

The results were also in line with the study conducted by Scharader stating that the ability to conduct daily life activities (ADL) decreased with the declining status of nutrition. The proportion of patients who are unable to do ADL increases with the worsening of nutritional status (45.0\% vs 50.4\% vs. 77.0\%, p <0.01) [30]. Unlike the results of the study conducted by Casanova stating that no significant relationship was observed between physical activity and nutritional status [31]. 
Problems encountered in the elderly are lack of appetite, imperfect digestive processes, difficult bowel movements, and food utilization as an energy source. With this problem-oriented, can be designed a physical exercise that aims to increase appetite (input), facilitate the digestion and bowel processes (processes), and streamline the utilization of energy in the body (out put). As great as any nutrient composition is provided, if not eaten, processed, and utilized by the body, then it is not able to give results. After the elderly, most elderly reduce their physical activity, because stamina has decreased, have a certain health condition or because of the absence of opportunity. In fact, the elderly should be moving and physical activities every day, with the activity of bias preventing health problems as well as keeping the body in prime condition. Such as consuming supplements, vitamins or consuming eating and healthy drinks, physical activity is also able to prevent various diseases. Test results of the parameter coefficient between physical activity to the quality of life of elderly in the health center of Petaling Mendobarat Bangka Belitung showed a direct influence of $13.01 \%$ and T-Statistic value of 9.15 and significant at $\alpha=5 \%$ where physical activity performed can be proven to improve the quality of life physically and mentally. Improved physical quality of life, among others, increased metabolism glucose, strengthening of bones and muscles, and reducing cholesterol levels in the blood [32].

There are many different types of sports or physical activities for the elderly that can be tailored to the needs. For medium intensity, for example, close-up walking, house cleaning, leisurely cycling, stair climbing, and gardening. Meanwhile, heavy activities include swimming, Tai chi, yoga, jogging, fast walking, carrying children, to badminton [33].

\subsection{Contributions to age and intellectual function of activity}

The magnitude of the simultaneous age and mental contributions that have been on the basis of the elderly activity is $\mathrm{R}_{\text {square }}^{2}=0.0327$ or $3.27 \%$, the remainder of which is $96.73 \%$ influenced by other factors. The results were in line with the research result of Emile stating that the elderly with Deminsia suffered a mental breakdown of $12-50 \%$ of the conditions it affects in fulfilling its nutritional status and having difficulties in conducting daily activities [34].

\section{CONCLUSION}

There is no direct influence on the age of activity and its impact on nutritional status. There is a direct influence on the intellectual function of activity and its impact on nutritional status. The amount of indirect age of contribution to nutritional status is $0.0004 \%$. Contributions that do not directly affect the activity of $-0.220 \%$. Contribution of intellectual function directly to the nutritional status of $1.8 \%$. The contribution of intellectual function directly affects the activity by $16 \%$, the rest is influenced by other factors not described in this study. The solution to maintain the status of elderly nutrition in good condition is to stimulate the mental status of elderly by often engage and socialize by family and environment, to increase their physical activity routinely doing activities by following the activities of elderly, social community and the need for family support in presenting food for the elderly. It is expected that subsequent studies can continue with any contribution that can affect the nutritional status of the elderly.

\section{REFERENCES}

[1] Kemenkes RI, "Elderly Analysis in Indonesia," Data and information center Kementerian Kesehatan RI, pp. 1, 2017. [Online]. Available: https://pusdatin.kemkes.go.id/resources/download/pusdatin/lainlain/Analisis\%20Lansia\%20Indonesia\%202017.pdf

[2] Statistics of Boyolali, "Growth rate of Boyolali population," Central Statistic Agency Boyolali, 2018.

[3] Bøen H., Dalgard O. S., Bjertness E., "The importance of social support in the associations between psychological distress and somatic health problems and socio-economic factors among older adults living at home: a cross sectional study, " BMC Geriatrics, vol. 12, no. 27, pp. 1-12, 2012.

[4] Tulak GT, Munawira Umar D, "The effect of elderly gymnastics on blood pressure decrease elderly patients with hypertension in the health center of Wara Palopo," Perspektif, vol.1, no.1, pp. 160-72, 2017.

[5] Safitri N., "Elderly health problems," Kemenkes RI, 2018.

[6] Gale S. A., Acara D., Dafner K. R., "Dementia,” The America Journal of Medicine, vol.131, no.10, pp.1161-1169, 2018.

[7] A. Y., B. N., R. M., "Difference in quality with an elderly social," e-Journal Pustaka Kesehatan, vol. 2, no.1, pp. 87-94, 2014.

[8] Kementerian Kesehatan, "An overview of elderly health in Indonesia,"Kementerian Kesehatan RI, 2013.

[9] R. S. M, M. F. E., Rosdiana, "Getting to know their age and care.” 1st ed Salemba Medika, 2011. 
[10] Ongan D., Rakicioglu N., "Nutritional Status and Dietary Intake of Institutionalized Elderly in Turkey: A Cross-Sectional, Multi-Center, Country Representative Study," Archives of Gerontology and Geriatrics, vol. 61, no. 2, pp. 271-276, 2015.

[11] Mlinac M. E., Feng M. C., “Assessment of activities of daily living, self-care, and independence," Archives of Clinical Neuropsychology, vol. 31, no. 6, pp. 506-516, 2016.

[12] Welch D. C., West R. L., "The short portable mental status questionnaire," Stanford school of medicine Ethnogeriatric, vol. 48, no. 6, pp. 329-332, 2010.

[13] S. G. O., M. K. D., F. S., "Impact of nutritional supplementation during pregnancy on antibody responses to diphtheria-tetanus-pertussis vaccination in infants: Arandomised trial in The Gambia," PLOS Medicine, vol. 6, no. 16, 2019.

[14] Ibrahim, "Relationship factors affecting the nutritional needs in the UPTD House of Geunaseh Sayang, Banda Aceh,” Idea Nursing Journal, vol. 3, no. 2, pp. 51-62. 2012.

[15] Ariati N. N., Gumala N. M. Y., Nursanyoto H., "Macronutrient consumption relationship with the risk of premature aging in elderly who follow elderly gymnastics in Ganyar district Posyandu,"Jurnal Sangkareang Mataram, vol. 3, no. 3, pp. 34-37, 2017.

[16] Anindyaputri I.,“ How Much Physical Activity Older People Need?,”? (In Bahasa: Berapa Banyak Aktivitas Fisik yang Dibutuhkan Orang Lanjut Usia), Hello sehat, 2019.

[17] Antoniazzi L. D., Aballay L. R., Fernandez A. R., "The Nutritional Status Analysis in Physical Education Students, Associated With Eating Habits and Level of Physical Activity," Pubmed, vol. 75, no. 2, pp. 105-110, 2018.

[18] Abdinsyah Siregar, "5 Tips for preventing elderly depression," Golansia, 2019.

[19] Hp W., J. L., L. M. K., C. Y. C., Y. I. S., "Trajectories of nutritional status and cognitive impairment among older Taiwanese with hip fracture," The Journal of Nutrition, Health and Aging, vol. 21, no. 1, pp. 38-45. 2017.

[20] Chapman D. P., Perry G. S., "Depression as a major component of public health for older adults," Preventing Chronic Disease, vol. 5, no. 1, 2018.

[21] Gariballa S., Awad A., "Associations between low muscle mass, blood-borne nutritional status and mental health in older patients," BMC Nutrition, vol. 6, no. 6, 2020.

[22] Gracia M., Ortega A. L. J., Sobaler L., "Nutrition strategies that improve cognitive function," Nutrition Hospitalaria, vol. 35, no. 6, pp. 16-19, 2018

[23] Wang X., Liu M., Li Y., Guo C., Yeh C.H., "Community canteen services for the rural elderly: determining impacts on general mental health, nutritional status, satisfaction with life, and social capital," BMC Public Health, vol.20, no.230, pp.1-9, 2020.

[24] Eric G. T., Ronald C. P., "Mild cognitive impairment in geriatrics," Clinics in Geriatric Medicine, vol. 34, no. 4, pp. 563-589, 2018.

[25] Wahid B., Sudarma V., "Relationship of nutritional status and decreased cognitive function in elderly," Tri Jurnal Tri Sakti, vol. 1, no. 1, pp. 331-337, 2018.

[26] ArtazaI. A., "The Relationship between Nutrition and Frailty: Effects of Protein Intake, Nutritional Supplementation, Vitamin D and Exercise on Muscle Metabolism in the Elderly. A Systematic Review," Maturitas, vol. 93, pp. 89-99, 2016.

[27] Alfyanita A., Dinda Martini R., Kadri H., "Relationship of self-reliance in conducting daily life activities and nutritional status at the elderly in the social orphanage Tresna Werdha Sabai Nan Aluih Sicincin," Jurnal Kesehatan Andalas, vol. 5, no. 1, pp. 201-208, 2016.

[28] Indonesia P. G. M., "Nutrition management consensus in elderly people," 1st ed. Jakarta: Pengurus Besar PREGEMI, 2012.

[29] Lestari W., Weta I. W., "Elderly nutritional Status based on knowledge and physical activity, in the working area of Sukawati 1 Puskesmas, Gianya, Bali," JKK, vol. 4, no. 2, pp. 56-63, 2017.

[30] Schrader E., Baumgartel C. G., "Nutritional status according to Mini Nutritional Assessment is related to functional status in geriatric patients independent of health status," The Journal of Nutrition, Health and Aging, vol. 18, no. 3, pp. 257-263, 2014.

[31] Casanova L., Manas R., Loren Aznar, Al E., "Physical activity and nutritional and psychosocial status in nondependent elderly," Medicina de Familia. Semergen, vol. S1138-3593, no. 19, pp. 30445-30449, 2020.

[32] Savita R., "Influence of family role, physical activity, social interaction and stress to elderly life quality," Jurnal Ilmiah STIKES Citra Delima Bangka Belitung, vol. 2, no. 1, pp. 58-70, 2018.

[33] Direktorat Promosi Kesehatan dan Pemberdayaan Masyarakat, "Physical activity for the elderly," 2018. [Online]. Available: https://www.who.int/dietphysicalactivity/factsheet_olderadults/en/.

[34] Escourrow E., Durrieu F., Chicoulea B., "Cognitive, functional, physical, and nutritional status of the oldest old encountered in primary care: a systematic review," BMC Family Practice, vol. 21, no. 58, pp. 1-10, 2020. 